\title{
Organizational Career Growth and Turnover Intention: An Application in Audit Firms in Turkey
}

\author{
Gulsah Karavardar ${ }^{1}$ \\ ${ }^{1}$ Faculty of Economic and Administrative Sciences, Giresun University, Giresun, Turkey \\ Correspondence: Gulsah Karavardar, Faculty of Economic and Administrative Sciences, Giresun University, \\ Giresun, Turkey. Tel: 90-454-310-1300. E-mail: gkaravardar@yahoo.com
}

Received: July 9, 2014

Accepted: July 17, 2014

Online Published: August 25, 2014

doi:10.5539/ibr.v7n9p67

URL: http://dx.doi.org/10.5539/ibr.v7n9p67

\begin{abstract}
This study examined the direct effect of organizational career growth on turnover intention, as well as the buffering influence of organizational commitment on this relationship among auditors in Turkey. Organizational career growth was conceptualized by four factors: career goal progress, professional ability development, promotion speed and remuneration growth. Organizational commitment was conceptualized by three components: Affective commitment, normative commitment and continuance commitment. Data was obtained from 226 auditors from 92 audit firms in Turkey. According to results, organizational career growth dimensions, namely career goal progress, professional ability development, promotion speed and renumeration growth are all negatively related to turnover intention. Besides, it was found that professional ability development and renumeration growth have strong influences on turnover intention. In spite of this, career goal progress and promotion speed had no significant effect on turnover intention. According to the results of hierarchical multiple regression, there is not any buffering effect of organizational commitment (affective commitment, normative commitment and continuance commitment) on the relationship between each of the four dimensions of organizational career growth and turnover intention.
\end{abstract}

Keywords: organizational career growth, turnover intention, organizational commitment, auditors, Turkey

\section{Introduction}

The success of an organization is determined by its human resources. So, human resource is a vital competitive tool for organizations. Career growth implications are one of the important tools of retaining talented human resources in organizations. If organizations fail to retain its valuable human resources, they may face two kinds of costs. The first one is the direct cost. It consists replacement, recruitment and selection, temporary staff, and management time costs. The second one is the direct cost. It consists of decreasing morale and pressure on remaining staff and cost of training. Thus, for retaining the talented human resources, organizational career growth can be a helpful tool for organizations. Organizations' structures and management and also relations with employees have been changed (Arthur, Inkson, \& Pringle, 1999; Coyle-Shapiro, Shore, Taylor, \& Tetrick, 2004). The most important asset has become human resources among organizations' assets. According to some researchers quitting is a good indicator that the organization is in trouble (Clark, 2001; Kristensen \& Wastergard, 2004) with its human resources. To retain valuable employees, organizations should motivate and reward its employees. For doing this, organizations should make plans and take right steps to heighten affirmative acts among their employees (Seta et al., 2000). Many employees are satisfied if they have faith for a bright and well future in their current organizations (Drafke \& Kossen, 2002). Otherwise, employees may start thinking about quitting.

The social exchange theory asserts that employees and their employers share an exchange relationship. Besides, this relationship gets stronger as much as both parties have desire to fulfil each other's wishes. Thus, employee behaviour is mostly effected by organizations' human resources practices (in this present study, organizational career growth policy) through psychological contract. Psychological contract is defined as an employee's perception of what he or she expects from his or her organization in return for his or her perceived contributions to it (Rousseau, 1995; Robinson, 1996). Since it is an informal contract, the psychological contract between employees and their organizations is perceptual, generally implicit and subjective (Willems et al., 2003; Kabar \& Barrett, 2010). A psychological contract consists of employees' ideas, concerns or firm policy from an 
employee's point of view (Morrison \& Robinson, 1997). Since the career growth policy of an organization is an important encouraging issue (Bedeian et al., 1991), organizations should create psychological contracts through their career growth policies. The relation based on a psychological contract between an employee and his or her organization consists of the organization's motivation capability toward the employee and also this employee's desire to reach his or her organization's goals (Aselage \& Eisenberger, 2003). Thus, an organizational career growth policy should create solid sentiments of a psychological contract among employees especially when the organizational career growth policy of the organization is a valuable attempt for its employees (Bedeian et al., 1991) who anticipate progress and growth in their careers (Okurame \& Balogun, 2005; Okurame, 2012).

In the literature, researchers mainly focused on the process of growing in one's career (Sturges, Guest, Conway, \& Davey, 2002; Weng \& McElroy, 2009). They didn't focus on the outcomes of such efforts. Jans (1989) stated that career growth gets the outcomes of an employee's efforts by describing it as his or her perceptions of opportunities of improvement and advancement in an organization. According to Weng \& $\mathrm{Hu}$ (2009), oragnizational career growth can be explained by career goal progress, professional ability development, promotion speed, and remuneration growth. According to Weng \& Hu's (2009) study, career growth may also be interpreted as fulfillment of engagements by the organization as a psychological contract that sequentially exposed to be positively related to organizational commitment of employees (Coyle-Shapiro \& Morrow, 2006).

To the the best of the author's knowledge, there is not any related research which consists all variables, namely organizational career growth, organizational commitment and turnover intention, of this study in the literature. Besides, testing these relationships in a developing country will make a valuable contribution to the existing literature. This present research focused on auditors to examine the relationship among organizational career growth, organizational commitment (as a moderator) and turnover intention This present study analyzed the direct effect of organizational career growth on turnover intention, as well as the moderating effect of organizational commitment on this relationship among auditors in Turkey.

\section{Literature Review}

Relationships among Organizational Career Growth, Organizational Commitment and Turnover Intention:

According to the literature the relation between organizational career growth and organizational commitment can be indicated by two ways. The first one is ascending the stair of the hierarchy of the organization through a promotion and the second one is the rising career development experiences (Milliman, 1992; Brutus et al., 2000). Weer (2006) described career growth as the probability that an employee gets a promotion and acquires career development experiences from ascended responsibilities and contender tasks. Allen \& Meyer (1990), defined organizational commitment as "employees with strong affective commitment remain because they want to, those with strong continuance commitment because they need to, and those with strong normative commitment because they feel they ought to". Solinger et al. (2008) suggested that the differences among these dimensions show that the three forms of commitment are qualitatively different notions.

Affective commitment can be defined as employees' loyalty and willingness to stay with their organizations (Meyer, Allen, \& Smith, 1993). According to Meyer et al. (1993), when employees are satisfied by their organizations, their affective commitment will be affected positively. Reaching career goals and gaining professional ability improvement disclosure higher need satisfaction while promotion and remuneration enable assess how an employee is considered by his or her organization. According to Tsui, Pearce, Porter, \& Tripoli (1997), for creating an employee-organizational relationship which has a mutual benefit, organizations should let their employees to experience career growth. When such an environment is created in an organization, employees feel higher agreement and affective organizational commitment toward their organizations (Hom et al., 2009). Affective commitment discusses employees' willingness to remain with their present employers and shows the inherent of their association.

Meyer et al. (1993) defined normative commitment as the psychological attachment of an employee toward his or her organization based on socialization experimentations or a moral obligations. In supporting this view, Wiener (1982) asserted that employees who have high normative commitment remain in their present organizations since they feel it is the right and moral thing to do. According to norms of reciprocity, an individual should support and not damage the people who have supported him or her (Gouldner, 1960). Normative commitment is built on norms of reciprocity (Meyer \& Herscovitch, 2001). Wiener (1982) asserted when an organization gives financial support to its employees' education, this develops these employees' moral obligation. Normative commitment defines an employee's willingness to stay with any employer and it shows an employee's thoughts about the nature of the employer-employee association (Solinger et al., 2008). Normative commitment reminds Briscoe et al.'s (2006) measure of boundaryless career orientation. It is called as 
'organizational mobility preference'. Meyer \& Herscovitch (2001) added that normative commitment is associated with consenting the organization's advantages. The advantages of the organizations are usually training advantages and mentoring programs, besides, promotions and raises can be taken into account as well.

Continuance commitment can be defined a feeling of a commitment to an organization since employees feel they have to stay (Meyer et al., 1993). Meyer \& Allen (1991) asserted that any agent which raises the perceived costs of quitting may be expressed as a predictor of continuance commitment. According to Hom et al. (2009), these costs can be seniority, a job skill that belongs to only present organization which is impossible to transfer to another organization, movement of family or leaving behind of fellowship and colleague networks. Continuance commitment discusses the attitude toward respecting the objective or instrumental results of remaining or quitting.

Alvi \& Ahmed's (1987) research results showed that when employees think their organizations have high promotional opportunities, they show higher levels of organizational commitment. According to literature, the variables that effect commitment of employees can be listed as: personal development opportunity (Liu \& Wang, 2001), promotion equity and training (Long, Fang, \& Ling, 2002) and opportunity for learning (Ng, Butts, Vandenberg, DeJoy, \& Wilson, 2006). Weng \& Hu (2009) asserted organizational career growth involves reaching career aims, improving professional skills and getting promotions and compensation appropriate with those competences. Weng \& McElroy (2012) studied on both career growth and its influence on occupational commitment and turnover intentions. According to their research results, career growth dimensions were negatively related to turnover intentions and affective occupational commitment was found as a partial mediator on their relationships. Hess, Jepsen \& Dries (2012) studied the direct influence of individual career concerns on career and employer change intention, as well as the buffering influence of organizational commitment on that relationship. Their study results asserted that exploration concerns related positively to both employer and career change intentions; the impact of exploration concerns on career change intention was moderated by affective commitment, but, and reinforced by normative commitment. Establishment concerns related negatively to career change intention, and this influence was also moderated by level of affective commitment.

According to the literature summary, it can be deduced that, when organizations provide satisfactory career growth environment to their employees, by supporting them reaching their career goals and improving their professional skills, and awarded them by promotions and remuneration, these employees are much more ready to reciprocate and enhance a sense of moral obligation to their organizations and also think no more resignation. According to the social exchange hypothesis of the influences of an organizational career growth policy on a psychological contract, a favourable career growth prospects formed from affirmative experiences with the policy should create a greater requirement for employees to repay the organization with retaining in their current jobs. Besides, it is suggested that through the mechanisms outlined above, each form of organizational commitment, namely affective, normative and continuance commitment, will act as a buffer between organizational career growth factors and turnover intention.

\section{The Model and Hypotheses}

The model of the study is given in Figure 1. According to the review of the literature, two central hypotheses are formulated as:

Hypothesis 1. Organizational career growth factors have a direct effect on turnover intention.

Hypothesis 2. The impact of organizational career growth factors on turnover intention is moderated by organizational commitment.

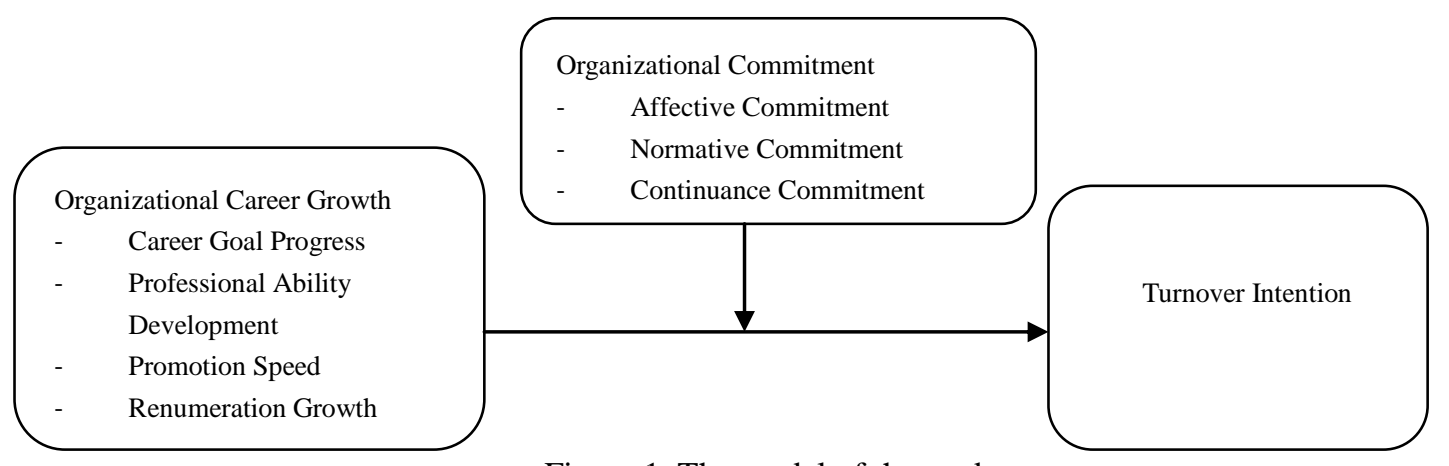

Figure 1. The model of the study 


\section{Method}

\subsection{Data Collection and Sample}

According to 'Accounting and Auditing Standarts Association', there are 92 audit firms in Turkey (www.kgk.gov.tr). The auditors who work in these audit firms are focused in this study. Data were collected from March to April 2014 via e-mails. A questionnaire was prepared and randomly e-mailed to these firms to be delivered to their auditors who were volunteered to participate. 226 completed forms were taken.

\subsection{Measurements}

The scale of organizational career growth was taken from Weng \& Hu's (2009) study. It is a 15-item scale and has four dimensions. Samples for the scale's items are "My present job provides me with good opportunities to realize my career goals" and "My present job moves me closer to my career goals" for career goal progress dimension; " My present job encourages met o continuously gain new and job related skills" and "My present job encourages met o accumulate richer work experiences" for professional ability development dimension; "My promotion speed in the present organization is fast" and "Compared with my collegues, I am being promoted faster" for promotion speed dimension, and "My salary is growing quickly in my present organization" and "In this organization, the possibility of my current salary being increased is very large" for remuneration growth dimension. The coefficient alpha values for career goal progress professional ability development, promotion speed and remuneration growth are $0.85,0.86,0.80$, and. 78 , respectively.

To measure the organizational commitment of participants, Meyer \& Allen's (1997) scale was used. It is a six-item scale and has three dimensions. These dimensions are affective commitment, continuance commitment and normative commitment. Sample items are "I would be very happy to spend the rest of my career with this organization" (affective commitment); "Right now, staying with my organization is a matter of necessity as much as desire" (continuance commitment); "Even if it were to my advantage, I do not feel it would be right to leave my organization now" (normative commitment). The coefficient alpha values for affective commitment, continuance commitment, and normative commitment scales are $0.86,0.84$, and 0.78 , respectively.

Researchs has shown that employees' turnover intentions is the best predictor of actual turnover (Bedeian et al.; 1991; Steel, 2002). Since the actual data is unavailable, turnover intention scale was used. This scale is developed by Kelloway, Gottlieb, \& Barham's (1999). It is a 4-item measurement. These items are "I am thinking about leaving this organization", "I am planning to look for a new job", "I intend to ask people about new job opportunities", and "I don't plan to be in this organization much longer". Their coefficient alpha was 0.76. The coefficient alpha in this present study is 0.78 . The coefficient alpha results, that have presented so far, are fulfilled the rule of acceptable value suggested by Nunally (1978).

During adaptation of the measures into Turkish, the method of Brislin, Lonner \& Thorndike (1973) was used, which consisted of four steps: forward translation, assessment of forward translation, backward translation, and assessment of backward translation. All of the scales were translated into Turkish by the researcher and reviewed by a colleague who is native in both Turkish and English and an assistant professor of English to assure the clarity of terminology.

\subsection{Analyses}

A confirmatory factor analysis was applied to determine the validity of organizational career growth as a four component model. This analysis was used to compare the fitness of the one-dimensional model (all items share the same factor), two-dimensional model (the first factor is career goal progress and professional ability development, and the second one is promotion speed and remuneration growth), three-dimensional model (promotion speed and remuneration growth share a factor) and four-dimensional model. According to the confirmatory factor analysis, the fitness of the four-dimensional model (Chi-Squares/df=1.512, GFI=.94, AGFI=.92, RMSEA=.061, NNFI=.95, CFI=.94) is the best model (Schermelleh-Engel \& Moosbrugger, 2003).

After that, a confirmatory factor analysis was applied to establish the validity of organizational commitment as a three component model. According to Weng, McElroy, Morrow \& Liu (2010) and Chen \& Francesco's (2003) studies the fitness of the one-dimensional model (all items share the same factor), two-dimensional model (affective and normative commitment share a factor), three-dimensional and four-dimensional model (continuous commitment is divided into two factors) were evaluated. According to the confirmatory factor analysis, the three-dimensional model (Chi-Squares/df=2.08, GFI=.91, $\mathrm{AGFI}=.88, \mathrm{RMSEA}=.067, \mathrm{NNFI}=.95, \mathrm{CFI}=.93$ ) is the best model (Schermelleh-Engel \& Moosbrugger, 2003).

After completing validity tests of scales, the correlation analyses conducted. Correlation analysis provides information about the relationship between dependent and independent variables. Since correlation analyses do 
not present the strength of the relationships between variables, a hierarchical multiple regression analysis was conducted. First of all, all study variables were centred prior to being entered into the regression model. Since age, organization tenure and career tenure variables have repeatedly been shown to impact on career issues, organizational commitment and turnover intentions (Weng, McElroy, Morrow \& Liu, 2010; Allen \& Meyer, 1993; Bedeian et al., 1991; Cohen, 1993; Cooke, 1994; Pettit et al., 2004), in the first step, age, organization tenure, career tenure, and also position tenure were controlled.

Controlling for age and tenure allows conclusions on the influences of organizational career growth on turnover intention at any point in an individual's life and (organizational) career (Weng, McElroy, Morrow \& Liu, 2010). For testing this present study's first hypothesis, organizational career growth dimensions and organizational commitment dimensions were entered at the second step. To test the second hypothesis, the two-way interaction among the four organizational career growth and three types of organizational commitment were entered at the third step.

\section{Results}

Table 1 shows means, standard deviations and correlations among this study's variables. Cronbach alpha coefficients are also shown on the diagonal where applicable in the table. As it can be seen in the Table 1, career goal progress $(r=-.14, p<.05)$, professional ability development $(r=-.36, p<.01)$, promotion speed $(r=-.15, p<.05)$, and renumeration growth $(\mathrm{r}=-.37, \mathrm{p}<.01)$ all have negative relationships with turnover intention. Besides, only affective commitment has a positive relation with career goal progress $(r=.19, \mathrm{p}<.05)$, professional ability development $(r=.29, \mathrm{p}<.05)$, promotion speed $(\mathrm{r}=.18, \mathrm{p}<.05)$, and renumeration growth $(\mathrm{r}=.24, \mathrm{p}<.05)$. Affective commitment $(\mathrm{r}=-.37, \mathrm{p}<.01)$ and normative commitment $(\mathrm{r}=-.18, \mathrm{p}<.05)$ have negative relationships with turnover intention.

Research data collected from private audit firms in Turkey. All participants are auditors. They were asked for their age, career tenure, organization tenure and position tenure to control these variables in the regression analysis. The mean values of their age, career tenure, organization tenure and position tenure were 34.23, 7.25, 3.17 and 1.84 , respectively.

Table 2 presents the beta coefficients, standard errors, and $\mathrm{R}^{2}$ as a result of the hierarchical multiple regression. According to the results of the hierarchical multiple regression, the control variables (age, organization tenure, career tenure and position tenure) presented a significant influence on turnover intention $(\mathrm{R} 2=.02 ; \mathrm{F}=2.74$, $\mathrm{p}<0.05)$ in the Table 2 . This effect is primarily because of career tenure $(\beta=-.04, p<.05)$ and organization tenure $(\beta=-.02, \mathrm{p}<.05)$.

As it can be seen in Table 2, higher professional ability development associated with lower turnover intention $(\beta=-.44, \mathrm{p}<.05)$. Besides, higher renumeration growth associated with lower turnover intention $(\beta=-.41, \mathrm{p}<.05)$. None of the other organizational career growth dimensions were significant predictors of turnover intention. Thus, hypothesis 1 was partially supported. In addition to that, higher affective commitment $(\beta=-.57, \mathrm{p}<.01)$ and normative commitment $(\beta=-.52, \mathrm{p}<.01)$ led to lower turnover intention in Step 2. In the Step 3, interaction variables were entered to the model. Despite of higher affective and normative commitment, there was not a significant change to the model and no significant interaction effects occured. Thus, hypothesis 2 was not supported. 
Table 1. Means, standart deviations, and correlations

\begin{tabular}{|c|c|c|c|c|c|c|c|c|c|c|c|c|c|c|}
\hline Variable & $\mathrm{M}$ & SD & 1 & 2 & 3 & 4 & 5 & 6 & 7 & 8 & 9 & 10 & 11 & 12 \\
\hline 1.Age & 34.23 & 8.16 & - & & & & & & & & & & & \\
\hline $\begin{array}{l}\text { 2.Organization } \\
\text { Tenure }\end{array}$ & 3.17 & 3.84 & $.15^{* *}$ & - & & & & & & & & & & \\
\hline 3.Career Tenure & 7.25 & 5.23 & $.17 * *$ & $.18^{* *}$ & - & & & & & & & & & \\
\hline $\begin{array}{l}\text { 4.Position Tenure } \\
\text { 5.Career Goal }\end{array}$ & 1.84 & 1.86 & $.13 * *$ & $.13 * *$ & $.18^{* *}$ & - & & & & & & & & \\
\hline $\begin{array}{l}\text { Progress } \\
\text { 6.Professional } \\
\text { Ability }\end{array}$ & 3.28 & .97 & $.14 *$ & $.17 *$ & $.21^{*}$ & $.21 * *$ & $(.85)$ & & & & & & & \\
\hline $\begin{array}{l}\text { Development } \\
\text { 7.Promotion }\end{array}$ & 3.57 & .94 & $.16^{*}$ & $.19 *$ & $.23 * *$ & $.22 *$ & $.24 * *$ & $(.86)$ & & & & & & \\
\hline $\begin{array}{l}\text { Speed } \\
\text { 8.Renumeration }\end{array}$ & 3.42 & .93 & $.18^{*}$ & $.15^{*}$ & $.19^{* *}$ & $.17^{*}$ & $.22 * *$ & $.25^{*}$ & $(.80)$ & & & & & \\
\hline $\begin{array}{l}\text { Growth } \\
\text { 9.Affective }\end{array}$ & 3.08 & .95 & $.21^{*}$ & $.18^{*}$ & $.17^{*}$ & .11 & $.21 * *$ & $.28 *$ & $.22 * *$ & $(.78)$ & & & & \\
\hline $\begin{array}{l}\text { Commitment } \\
\text { 10.Normative }\end{array}$ & 4.24 & 1.02 & $.18^{*}$ & $.14 *$ & .14 & .14 & $.19^{*}$ & $.29 *$ & $.18^{*}$ & $.24^{*}$ & $(.86)$ & & & \\
\hline $\begin{array}{r}\text { Commitment } \\
\text { 11.Continuance }\end{array}$ & 3.47 & .98 & $.22 *$ & $.13^{*}$ & .12 & .16 & .11 & .09 & .08 & .16 & $.21^{*}$ & $(.84)$ & & \\
\hline $\begin{array}{l}\text { Commitment } \\
\text { 12. Turnover }\end{array}$ & 4.16 & 1.17 & .11 & .10 & .13 & .19 & .08 & .07 & .06 & .09 & .11 & $.18^{*}$ & $(.78)$ & \\
\hline Intention & 2.67 & 1.24 & $-.16^{*}$ & -.22 & $-.19 * *$ & $-.22 *$ & $-.14 *$ & $-.36 * *$ & $-.15 *$ & $-.37 * *$ & $-.37 * *$ & $-.18 *$ & -.14 & $(.78)$ \\
\hline
\end{tabular}

Table 2. Hierarchical multiple regression analysis results $(\mathrm{N}=226)$

\begin{tabular}{|c|c|c|c|c|}
\hline \multirow[t]{2}{*}{ Turnover Intention } & \multicolumn{2}{|l|}{ Model } & \multicolumn{2}{|c|}{ Coefficients } \\
\hline & $\begin{array}{l}\mathrm{R}^{2} \\
(\mathrm{~F})\end{array}$ & $\begin{array}{l}\Delta R^{2} \\
(\Delta F)\end{array}$ & $\beta$ & SE \\
\hline Step 1. & .02 & .02 & & \\
\hline Intercept & $(2,74 *)$ & $(2.74 *)$ & $3.18^{*}$ & .11 \\
\hline Age & & & -.02 & .02 \\
\hline Organization Tenure & & & $-.02 *$ & .01 \\
\hline Career Tenure & & & $-.04 *$ & .16 \\
\hline Position Tenure & & & .06 & .01 \\
\hline Step 2. & .35 & .33 & & \\
\hline Intercept & $\left(13.07^{* *}\right)$ & $\left(17.63^{* *}\right)$ & $3.11 * *$ & .14 \\
\hline Age & & & .02 & .02 \\
\hline Organization Tenure & & & .02 & .02 \\
\hline Career Tenure & & & .04 & .03 \\
\hline Position Tenure & & & .09 & .13 \\
\hline Career Goal Progress & & & .18 & .11 \\
\hline Professional Ability Dev. & & & $-.44 *$ & .08 \\
\hline Promotion Speed & & & -.15 & .07 \\
\hline Renumeration Growth & & & $-.41 *$ & .11 \\
\hline Affective Com. & & & $-.57^{*}$ & .13 \\
\hline Normative Com. & & & $-.52 *$ & .09 \\
\hline Continuance Com. & & & -.34 & .12 \\
\hline Step 3. & .36 & .01 & & \\
\hline Intercept & $\left(5.87^{* *}\right)$ & $(.40)$ & $3.50 * *$ & .14 \\
\hline Age & & & .02 & .02 \\
\hline Organization Tenure & & & .02 & .02 \\
\hline Career Tenure & & & .04 & .04 \\
\hline Position Tenure & & & .09 & .06 \\
\hline Career Goal Progress & & & .29 & .18 \\
\hline Professional Ability Dev. & & & $-.45^{*}$ & .11 \\
\hline Promotion Speed & & & -.17 & .06 \\
\hline Renumeration Growth & & & $-.41 *$ & .14 \\
\hline Affective Com. & & & $-.56^{*}$ & .16 \\
\hline Normative Com. & & & $-.52 *$ & .09 \\
\hline Continuance Com. & & & -.28 & .12 \\
\hline $\mathrm{CGP}^{*} \mathrm{AC}$ & & & .11 & .07 \\
\hline CGP*NC & & & .09 & .04 \\
\hline $\mathrm{CGP} * \mathrm{CC}$ & & & .02 & .08 \\
\hline $\mathrm{PAD} * \mathrm{AC}$ & & & .14 & .05 \\
\hline $\mathrm{PAD}{ }^{*} \mathrm{NC}$ & & & .08 & .02 \\
\hline $\mathrm{PAD}^{*} \mathrm{CC}$ & & & .11 & .07 \\
\hline PS*AC & & & .16 & .14 \\
\hline PS*NC & & & .14 & .10 \\
\hline PS*CC & & & .17 & .08 \\
\hline RG*AC & & & .18 & .06 \\
\hline $\mathrm{RG}^{*} \mathrm{NC}$ & & & .14 & .07 \\
\hline $\mathrm{RG}^{*} \mathrm{CC}$ & & & .09 & .05 \\
\hline
\end{tabular}




\section{Discussion}

The purpose of this study is to examine the direct effect of organizational career growth on turnover intention, as well as the buffering influence of organizational commitment on this relationship among auditors in Turkey. For this purpose, first of all, the direct effect of each of the four dimensions of the organizational career growth on turnover intention was examined. It was found that professional ability development and renumeration growth have strong influences on turnover intention. In spite of this, career goal progress and promotion speed had no significant effect on turnover intention. Thus, hypothesis 1 was partially accepted. After testing direct effect of organizational career growth on turnover intention, the effects of affective commitment, normative commitment, and continuance commitment on the relationship between the organizational career growth and turnover intention were examined. Despite of higher affective and normative commitment, there was not a significant change to the model and no significant interaction effects occured. Thus, hypothesis 2 was not supported.

Organizational career growth has related to organizational commitment (Chang, 1999; Weng et al., 2010) in previous studies. However, only affective commitment has a relationship with organizational career growth factors in this study. This study's results assert that the greater professional ability development and renumeration growth provided by an organization make it less likely their employees think about leaving their jobs. It fits the theory of met expectations (Porter \& Steers, 1973) and the psychological contract. Bedeian et al., (1991) and Chang (1999) used a mechanism to explain this connection by organizational commitment (Bedeian et al., 1991; Chang, 1999). However, this present study's results partially agreed with their studies. According to Hess et al. (2012), with respect to professional ability development, the degree to which one is able to get new abilities in one's current place of employment can make employment there attractive. This finding supports the work of Bedeian et al. (1991) whose concept of expected utility of one's present job was based primarily on the degree to which one's present job was relevant to one's longer term professional growth and development (Hess et al., 2012). This study results support the works of Weng and McElroy (2012), Xiong (2008) and Hess et al.(2012). In Weng and McElroy's study, dimensions of career growth were negatively related to turnover intentions and affective occupational commitment was found to partially mediate these relationships among Chinese employees. In Xiong's (2008) study, it is demonstrated that remuneration growth constitutes one reason for employees to remain with their employing organizations among Chinese employees (Weng \& McElroy, 2012). Hess et al. (2012) found similar results among Australian employees.

The results of this present study should be viewed in the light of its limitations. First of all, turnover intentions have been shown to be a good predictor of actual turnover (Steel, 2002), however, they are not equivalent. Using actual turnover would help express these relationships better and remove thoughts related to common method bias. In addition to that, turnover intentions in this present study could be voluntary or involuntary. Besides, this study captured organizational career growth in terms of four factors originally proposed by Weng (2010). There may be other underlying dimensions that did not involved in this present study, so additional researchs may determine what other constitutes the organizational career growth needs. Data for the study are subject to the usual limitations of a survey research, as they were obtained from self-report instruments. Although study instruments are valid and reliable, this may not totally rule out under or over replies by participants. In addition to that, other individual differences or other potential variables (eg. perceived organizational support) that could influence the relationship between organizational career growth and turnover intention may be included in the future research. This study is exploratory; thus, data from auditors from the private auditing firms may not typify organizations in general. Additional studies in other sectors may confirm or deny whether this study's results can be supported.

\section{References}

Allen, N. J., \& Meyer, J. P. (1990). The measurement and antecedents of affective, continuance, and normative commitment to the organisation. Journal of Occupational Psychology, 63, 1-18. http://dx.doi.org/10.1111/j.2044-8325.1990.tb00506.x

Allen, N. J., \& Meyer, J. P. (1993). Organisational commitment: Evidence of career stage effects? Journal of Business Research, 26, 49-61. http://dx.doi.org/10.1016/0148-2963(93)90042-N

Alvi, S. A., \& Ahmed, S. W. (1987). Assessing Organizational Commitment in a Developing Country: Pakistan, A Case Study. Human Relations, 40(5), 267-280. http://dx.doi.org/10.1177/001872678704000502

Arthur, M. B., Inkson, K., \& Pringle, J. K. (1999). The new careers: individual action and economic change. London: SAGE Publications Ltd.

Aselage, J., \& Eisenberger, R. (2003). Perceived organizational support and psychological contracts: a 
theoretical integration. Journal of Organisational Behaviour, 24(5), 491-509. http://dx.doi.org/10.1002/job.211

Bedeian, A., Pizzolatto, A., Long, R., \& Griffith, R. (1991). The measurement and conceptualization of career stages. Journal of Career Development, 17, 153-166. http://dx.doi.org/10.1177/089484539101700301

Briscoe, J. P., Hall, D., \& DeMuth, R. F. (2006). Protean and boundaryless careers: An empirical exploration. Journal of Vocational Behavior, 69, 30-47. http://dx.doi.org/10.1016/j.jvb.2005.09.003

Brislin, R. W., Lonner, W. J., \& Thorndike, R. M. (1973). Cross-cultural research methods. New York: Wiley.

Brutus, S., Ruderman, M., Ohlott, P., \& McCauley, C. (2000). Developing from job experiences: the role of organisation-based self-esteem. Human Resource Development Quarterly, 11(4), 367-80. http://dx.doi.org/10.1002/1532-1096(200024)11:4<367::AID-HRDQ4>3.0.CO;2-6

Chang, E. (1999). Career commitment as a complex moderator of organizational commitment and turnover intention. Human Relations, 52, 1257-1278. http://dx.doi.org/10.1177/001872679905201002

Chen, Z. X., \& Francesco, A. M. (2003). The relationship between the three components of commitment and employee performance in China. Journal of Vocational Behavior, 62, 490-510. http://dx.doi.org/10.1016/S0001-8791(02)00064-7

Clark, A. E. (2001). What really matters in a job? Hedonic Measurement Using Quit Data. Labour Economics, 8, 223-242. http://dx.doi.org/10.1016/S0927-5371(01)00031-8

Cohen, A. (1993). Age and tenure in relation to organisational commitment: A meta analysis. Basic and Applied Social Psychology, 14, 143-159. http://dx.doi.org/10.1207/s15324834basp1402_2

Cooke, D. (1994). Measuring career stage. Human Resource Management Review, 4, $383-398$. http://dx.doi.org/10.1016/1053-4822(94)90020-5

Coyle, S., \& Morrow, P. (2006). Organizational and client commitment among contracted employees. Journal of Vocational Behavior, 68, 416-431. http://dx.doi.org/10.1016/j.jvb.2005.10.002

Coyle-Shapiro, J., Shore, L. M., Taylor, M. S., \& Tetrick, L. E. (2004). The Employment Relationship: Examining Psychological and Contextual Perspectives. Oxford University Press.

Drafke, M. W., \& Kossen, S. (2002). The human side of organizations (8th ed.). Upper Saddle River, New Jersey: Prentice Hall.

Goulder, A. W. (1960). The norm of reciprocity: a preliminary statement. American Sociological Review, 25(2), 161-78. http://dx.doi.org/10.2307/2092623

Hess, N., Jepsen, D. M., \& Dries, N. (2012). Career and employer change in the age of the 'boundaryless' career. Journal of Vocational Behavior, 81, 280-288. http://dx.doi.org/10.1016/j.jvb.2011.10.009

Jans, N. A. (1989). Organizational commitment, career factors and career/life stage. Journal of Organizational Behavior, 10, 247-266. http://dx.doi.org/10.1002/job.4030100305

Kabar, A. A., \& Barrett, B. (2010). The impact of the psychological contract on job satisfaction, OCB, and intent to leave in a continuing care retirement community. Retrieved from http://core.kmi.open.ac.uk/display/13602017 (accessed 07.04.2014)

Kelloway, E. K., Gottlieb, B. H., \& Barham, L. (1999). The source, nature, and direction of work and family conflict: A longitudinal investigation. Journal of Occupational Health Psychology, 4, 337-346. http://dx.doi.org/10.1037/1076-8998.4.4.337

Kristensen, N., \& Westergard, N. N. (2004). Does low Job Satisfaction lead to Job Mobility? IZA Discussion Paper No. 1026. Labour Markets. London, Routledge: McGraw-Hill.

Liu, X. P., \& Wang, Z. M. (2001). The study of organizational commitment and its development mechanism. Nankai Business Review, 4(6), 58-62.

Long, L. L., Fang, L. L., \& Ling, W. Q. (2002). Organizational career management: Measurement and its effects on employees' behavior and feelings in China. Acta Psychology Sinica, 24(1), 97-105.

Meyer, J. P., \& Allen, N. J. (1991). A three-component conceptualization of organizational commitment. Human Resource Management Review, 1(1), 64-98. http://dx.doi.org/10.1016/1053-4822(91)90011-Z

Meyer, J. P., \& Herscovitch, L. (2001). Commitment in the workplace: Toward a general model. Human Resource Management Review, 11, 299-326. http://dx.doi.org/10.1016/S1053-4822(00)00053-X 
Meyer, J. P., Allen, N. J., \& Smith, C. A. (1993). Commitment to organizations and occupations: Extension and test of a three-component conceptualization. Journal of Applied Psychology, 78, 538-551. http://dx.doi.org/10.1037/0021-9010.78.4.538

Milliman, J. F. (1992). Causes, consequences, and moderating factors of career plateauing. University of Southern California, Los Angeles, CA, unpublished doctoral dissertation.

Morrison, E. W., \& Robinson, S. L. (1997). When employees feel betrayed: a model of how psychological contract violation develops. Academy of Management Review, 22(1), 226-56. Retrieved from http://www.jstor.org.www2.lib.ku.edu:2048/stable/259230

Ng, T. W. H., Butts, M. M., Vandenberg, R. J., DeJoy, D. M., \& Wilson, M. G. (2006). Effects of management communication, opportunity for learning, and work schedule flexibility on organizational commitment. Journal of Vocational Behavior, 68(3), 474-489. http://dx.doi.org/10.1016/j.jvb.2005.10.004

Nunnally, J. C. (1978). Psychometric theory (2nd ed.). New York: McGraw-Hill.

Okurame, D. (2012). Impact of career growth prospects and formal mentoring on organisational citizenship behaviour. Leadership \& Organization Development Journal, 33(1), 66-85. http://dx.doi.org/10.1108/01437731211193124

Pettit, T., Donohue, R., \& De Cieri, H. (2004). Career stage, organisational commitment, and organisational citizenship behavior. Paper presented at the Australian and New Zealand Academy of Management.

Porter, L. W., \& Steers, R. M. (1973). Organization, work and personal factors in employee turnover and absenteeism. Psychological Bulletin, 80, 151-176. http://dx.doi.org/10.1037/h0034829

Robinson, S. L. (1996). Trust and breach of the psychological contract. Administrative Science Quarterly, 41, 574-599. http://dx.doi.org/10.2307/2393868

Rousseau, D. M. (1995). Psychological Contracts in Organisations. CA: Sage, Thousand Oaks.

Schermelleh-Engel, K., Moosbrugger, H., \& Müller, H. (2003). Evaluating the fit of structural equation models: Test of significance and descriptive goodness-of-fit measures. Methods of Psychological Research-Online, $8(2), 23-74$.

Seta C. E., Paulus, P. B., \& ve Baron, R. A. (2000). Effective Human Relations a Guide to people at Work (4th ed.). USA: Alllyn and Bacon.

Solinger, O., Van Olffen, W., \& Roe, R. A. (2008). Beyond the three-component model of organizational commitment. Journal of Applied Psychology, 93(1), 70-83. http://dx.doi.org/10.1037/0021-9010.93.1.70

Steel, R. P. (2002). Turnover theory at the empirical interface: Problems of fit and function. Academy of Management Review, 27(3), 346-360.

Sturges, J., Guest, D. E., Conway, N., \& Mackenzie Davey, K. (2002). A longitudinal study of the relationship between career management and organisational commitment among graduates in the first the first ten years at work. Journal of Organisational Behavior, 23, 731-749. http://dx.doi.org/10.1002/job.164

Tsui, A., Pearce, J., Porter, L., \& Tripoli, A. (1997). Alternative approaches to the employee-organization relationship: Does investment in employees pay off? Academy of Management Journal, 40, 1089-1121. http://dx.doi.org/10.2307/256928

Weer, C. H. (2006). The impact of non-work role commitment on employees career growth prospect. Retrieved from http://idea.library.drexel.edu/bitstream/1860/1165/1/weer_christy. pdf

Weng, Q., \& McElroy, J. (2012). Organizational career growth, affective occupational commitment and turnover intentions. Journal of Vocational Behavior, 80, 256-265. http://dx.doi.org/10.1016/j.jvb.2012.01.014

Weng, Q. X. (2010). Career Growth Study: Scale development and validity test. Management Review, 22(10), 22-31.

Weng, Q. X., \& Hu, B. (2009). The structure of career growth and its impact on employees' turnover intention. Industrial Engineering and Management, 14(1), 14-21.

Weng, Q. X., \& McElroy, J. C. (2009). Vocational self-concept crystallization as a mediator of the relationship between career self-management and job decision effectiveness. Journal of Vocational Behavior, 76(2), 234-243. http://dx.doi.org/10.1016/j.jvb.2009.10.012

Weng, Q., McElroy, J. C., Morrow, P. C., \& Liu, R. (2010). The relationship between career growth and 
organisational commitment. Journal of Vocational Behavior, 77, 391-400. http://dx.doi.org/10.1016/j.jvb.2010.05.003

Wiener, Y. (1982). Commitment in organizations: A normative view. Academy of Management Review, 7, 418-428.

Willems, I., Henderick, E., Janvier, R., \& De Prins, P. (2003). Psychological contract in the Belgian Federal Civil Service. EGPA Annual Conference, Oeiras, September.

Xiong, L. M. (2008). Researching on the moderating effects of the organizational identification in the decision of employee turnover intention. Soft Science, 22(7), 64-69.

\section{Copyrights}

Copyright for this article is retained by the author(s), with first publication rights granted to the journal.

This is an open-access article distributed under the terms and conditions of the Creative Commons Attribution license (http://creativecommons.org/licenses/by/3.0/). 